\title{
KETEPATAN PENGGUNAAN PREPOSISI DALAM KARANGAN SISWA KELAS III, IV, V, DAN VI
}

\author{
Sumadi, Novi Eka Susilowati \\ Jurusan Sastra Indonesia Fakultas Sastra Universitas Negeri Malang
}

\begin{abstract}
This study aims at describing the appropriate and correct use of prepositions in elementary school students' composition. The design of this study is qualitative research combined with formal approaches for students in grade 3, 4, 5 and 6 . The results of the study indicate that (1) there is a preposition used in all grades; (2) there are some prepositions used in certain grade; (3) some preposition functions are found in all grades; and (4) some preposition functions are found in certain grades.
\end{abstract}

Keywords: appropriateness, use, preposition, composition

\begin{abstract}
Abstrak: Fokus penelitian ini adalah mendeskripsikan ketepatan penggunaan preposisi dalam karangan siswa kelas III, IV, V, dan VI SD. Penelitian ini dilakukan dengan menggunakan pendekatan penelitian kualitatif yang dipadukan dengan pendekatan pendekatan formal. Hasil penelitian ini ada dua.Pertama, penelitan tentang wujud preposisi menghasilkan temuan, yaitu (1)ada preposisi yang digunakan di semua jenjang kelas,dan (2)ada preposisi yang digunakan di jenjang kelas tertentu saja. Kedua, Kedua, penelitan tentang wujud preposisi menghasilkan temuan, yaitu (1) ada fungsi preposisi yang ditemukan dalam karangan siswa di semua jenjang kelas; dan (2) ada fungsi preposisi yang ditemukan hanya dalam karangan siswadi semua jenjang kelas.
\end{abstract}

Kata-kata kunci: ketepatan, penggunaan, preposisi, karangan

Ada beberapa alasan dilakukannya penelitian ini. Alasan tentang pentingnya penelitian penggunaan preposisi dalam karangan siswa SD dikemukakan berikut. Pertama, ada katakata tertentu yang bentuknya sama tetapi dari sisi penggunaannya pada saat tertentu dapat dikategorikan sebagai preposisi dan pada saat yang lain dapat dikategorikan sebagai konjungsi, misalnya kata untuk, dalam, sejak, dengan, dan sebagainya. Masing-masing kata tersebut pada suatu waktu dapat berdiri sebagai preposisi, tetapi di waktu yang lain dapat berdiri sebagai konjungsi seperti tampak dalam kalimat (01) dan kalimat (02) berikut. Sementara itu, ada preposisi yang tidak pernah dapat menjadi konjungsi.

(01) Dia pergi ke sekolah dengan kakak.

(02) Dia pergi ke sekolah dengan membawa tas. 
Pada kalimat (01) dan (02) terdapat kata dengan. Kata dengan pada kalimat (01) berfungsi sebagai preposisi yang ditandai dengan diikutinya kata (bukan klausa)sebagai petanda, sedangkan pada kalimat (02), kata dengan berfungsi sebagai konjungsi yang ditandai dengan diikutinya klausa sebagaisebagai petanda. Dalam kalimat (01) yang mengikuti kata dengan tidak berpredikat, sedangkan pada kalimat (02) yang mengikuti dengan berpredikat, yaitu membawa. Sementara itu, preposisi ke pada kedua kalimat itu tidak pernah dapat menjadi konjungsi.Keadaan seperti ini tentu sangat menarik untuk diteliti dalam rangka mengembangkan keilmuan bahasa, khususnya ilmu bahasa Indonesia.

Kedua, karangan merupakan penggunaan bahasa yang sesungguhnya yang digunakan penulis untuk menyampaikan informasi kepada pembacanya secara tepat. Oleh karena itu, agar dapat menyampaikan informasi secara tepat kepada pembacanya, penulis harus menguasai berbagai komponen berbahasa, salah satu di antaranya adalah menguasai penggunaan preposisi. Kesalahan penggunaan preposisi akan berakibat kesalahan penyampaian informasi kepada pembacanya seperti tampak pada kalimat (03) dan kalimat (04) berikut.

(03) Saat ini ayah sedang di pasar.

(04) Saat ini ayah sedang ke pasar.

Kalimat (03) dan (04) masing-masing terdiri atas tiga konstituen, yaitu konstituen yang menduduki fungsi Ket, konstituen yang menduduki S, dan konstituen yang menduduki fungsi P. Konstituen yang menduduki fungsi Ket kedua kalimat itu sama, yaitu saat ini. Konstituen yang menduduki $\mathrm{S}$ kedua kalimat itu juga sama, yaitu ayah. Konstituen yang menduduki fungsi $\mathrm{P}$ pada kedua kalimat itu juga hampir sama. Perbedaannya terletak pada penggunaan preposisi di pada $\mathrm{P}$ kalimat (03) dan penggunaan preposisi ke pada $\mathrm{P}$ kalimat (03). Perbedaan penggunaan preposisi tersebut mengakibatkan makna kedua kalimat tersebut juga berbeda. Pada kalimat (03), penggunaan preposisi di menunjukkan bahwa ayahsedang berada di pasar. Sementara itu, pada kalimat (04), penggunaan preposisi ke menunjukkan bahwa ayah belum berada di pasar, melainkan sedang menuju ke pasar.

Ketiga, penggunaan preposisi yang tepat akan menentukan kejelasan makna sebuah kalimat. Dengan digunakannya preposisi yang tepat, makna sebuah kalimat menjadi jelas. Sebaliknya, digunakannya preposisi yang salah akan mengakibatkan makna kalimat menjadi tidak jelas, bahkan akan menjadi salah dan tidak sesuai dengan maksud penutur seperti tampak dalam kalimat berikut ini.

(05) Dia mendapatkan uang dari atasannya.

(06) Dia mendapatkan uang untuk atasannya.

Dari kedua kalimat itu tampak jelas bahwa penggunaan preposisi yang berbeda menyebabkan makna kalimat itu berbeda. Dalam kalimat (05), penggunaan preposisi dari dalam konstituen yang menduduki fungsi Ket berimplikasi bahwa konstituen yang menduduki fungsi Ket itu menyatakan makna 'asal dia mendapatkan uang'. Sementara itu, dalam kalimat (06), penggunaan preposisi untuk dalam konstituen yang menduduki fungsi Ket berimplikasi bahwa konstituen yang menduduki fungsi Ket itu menyatakan makna 'tujuan (yang berkepentingan dan akan menerima) dia mendapatkan uang'

Keempat, penggunaan preposisi yang tepat dapat digunakan untuk menambah dan atau melengkapi informasi yang disampaikan dalam kalimat itu. Tambahan atau kelengkapan informasi dalam kalimat dapat disampaikan melalui konstituen yang menduduki fungsi Ket pada kalimat itu. Pada sebuah kalimat yang diperluas dengan adanya keterangan, kehadiran preposisi dapat menambah atau melengkapi informasi yang berada dalam keterangan 
tersebut.Kalimat (07) berikut merupakan kalimat yang hanya terdiri atas dua konstituen, yaitu konstituen yang menduduki fungsi $\mathrm{S}$ dan konstituen yang menduduki fungsi $\mathrm{P}$, dan tidak ada konstituen yang menduduki fungsi Ket.Pada kalimat ini konstituen yang menduduki fungsi $\mathrm{S}$ adalah seminar itu dan konstituen yang menduduki fungsi $\mathrm{P}$ adalah sudah dilaksanakan.

(07) Seminar itu sudah dilaksanakan.

Meskipun kalimat itu sudah berterima, namun bisa jadi pembaca membutuhkan informasi tambahan karena pembaca merasa bahwa informasi yang disampaikan dalam kalimat itu masih kurang, misalnya, pembaca membutuhkan informasi tentang penyelenggara, sasaran, waktu pelaksanaan, dan sebagainya. Dalam hal ini, peran preposisi sangat penting untuk melengkapi informasi yang disampaikan dalam kalimat itu, misalnya, dengan menambah informasi yang disampaikan dalam konstituen yang menduduki fungsi Ket seperti tampak dalam kalimat berikut.

(07a) Seminar itu sudah dilaksanakan oleh mahasiswa.

(07b) Seminar itu sudah dilaksanakan untuk mahasiswa.

Kalimat (07a) dan kalimat (07b) merupakan dua variasi bentuk perluasan kalimat (07) dengan menambahkan informasi tambahan yang disampaikan dalam konstituen yang menduduki fungsi Ket. yang menggunakan preposisi. Pada kalimat (07a), penambahan informasi dilakukan dengan menambah konstituen kalimat yang menduduki fungsi Ket dengan menggunakan preposisi oleh, sedangkan pada kalimat (07b) penambahan informasi dilakukan dengan menambah konstituen kalimat yang menduduki fungsi Ket dengan menggunakan preposisi untuk. Perbedaan penggunaan preposisi tersebut berimplikasi pada kelengkapan makna yang terkandung dalam kedua kalimat tersebut. Pada kalimat (07a), penggunaan preposisi oleh memberikan informasi bahwa pelaku/ penyelenggara kegiatan seminar adalah mahasiswa, sedangkan pada kalimat (07b), penggunaan preposisi untuk memberikan informasi bahwa sasaran kegiatan seminar tersebut adalah mahasiswa.

Penelitian ini dilakukan terhadap preposisi dalam karangan siswa kelasIII, IV, V, dan VI SD. Meskipun demikian, penelitian ini pada hakikatnya bukan penelitian pembelajaran, melainkan penelitian bahasa dalam penggunaan sebagaimana dikemukakan di atas. Alasan dilakukannya penelitian tentang ketepatan penggunaan preposisi dalam karangan siswa kelas III, IV, V, dan VI SD adalah pertimbangan manfaat praktis. Dari aspek pembelajaran, hasil penelitian ini bermanfaat bagi guru untuk mengetahui kecenderungan ketepatan penggunaan preposisi dalam karangan siswa kelas III, IV, V, dan VI SD sehingga guru dapat meningkatkan kualitas pembelajaran. Di samping itu, sudah menjadi fakta yang tidak terbantahkan bahwa salah satu kompetensi yang harus dimiliki siswa dalam pembelajaran bahasa Indonesia adalah kompetensi menulis. Dengan tulisan, penulis dapat mengungkapkan berbagai pikiran, perasaan, dan kemauan kepada orang lain tanpa harus berhadapan langsung dengan orang yang diajak berkomunikasi (Nurchasanah \& Widodo, 1993:5). Dalam menulis atau mengarang, salah satu aspek yang harus dikuasai oleh penulis adalah penggunaan preposisi.

Penelitian yang sejenis dengan penelitian ini sebenarnya sudah pernah dilakukan. Rofila (2006) mengadakan penelitian dengan judul Penggunaan Preposisi dalam Karangan Siswa Kelas VIII SMP Negeri 4 Malang Tahun Ajaran 2005/2006. Hasil penelitian Rofila menunjukkan bahwa preposisi yang digunakan siswa adalah (1) preposisi monomorfemis, (2) preposisi polimorfemis berafiks, (3) preposisi polimorfemis gabungan preposisi dengan preposisi, dan (4) preposisi polimorfemis gabungan preposisi dengan bukan preposisi. Hidayah (2007) mengadakan penelitian dengan judul Analisis Preposisi dalam Karangan 
Siswa Kelas IV SD Negeri Kasin Kota Malang Tahun Ajaran 2006/2007. Hasil penelitian ini menunjukkan bahwa wujud atau jenis preposisi yang telah ditemukan dalam karangan siswa kelas IV SD Negeri Kasin adalah preposisi monomorfemis, preposisi polimorfemis, preposisi berafiks, preposisi gabungan antara preposisi dan preposisi, serta preposisi gabungan antara preposisi dengan bukan preposisi. Hasil penelitian ini juga menunjukkan bahwa ketepatan penggunaan preposisi dalam penelitian tersebut meliputi ketepatan teknik penulisan, ketepatan pemilihan jenis preposisi, dan penggunaan preposisi secara proporsional.

Penelitian ini memiliki persamaan dan perbedaan dengan penelitian sebelumnya. Persamaan penelitian ini dengan penelitian sebelumnya terletak pada fokus penelitian, yaitu sama-sama meneliti ketepatan preposisi dalam karangan siswa. Apabila dikaitkan dengan penelitian Hidayah, penelitian ini memiliki kesamaan dengan salah satu fokus penelitian Hidayah, yaitu tentang ketepatan penggunaan preposisi dalam karangan siswa SD. Meski demikian, penelitian ini berbeda dengan penelitian-penelitian sebelumnya. Pertama, penelitian yang dilakukan oleh Hidayah dilakukan di SDN Kasin Kota Malang, sedangkan penelitian ini dilakukan di SDN Ardirejo 1, SDN Kedungpedaringan 1, SDN Kepanjen 2, dan SDN Cepokomulyo 1 yang terletak di Kecamatan Kepanjen Kabupaten Malang. Kedua, penelitian ini tidak berusaha menganalisis frasa preposisi dan kaidah pembentukan frasa preposisinya, melainkan hanya menganalisis ketepatan penggunaan preposisinya saja. Ketiga, penelitian ini berusaha menganalisis ketepatan preposisi berdasarkan jenjang kelas subjek penelitian, sedangkan penelitian lainnya hanya meneliti subjek penelitian di satu jenjang kelas saja. Berdasarkan paparan di atas, penelitian ini penting untuk dilakukan.

\section{METODE}

Penelitian ini dilakukan dengan menggunakan pendekatan penelitian kualitatif. Pendekatan penelitian kualitatif dalam penelitian ini dipadukan dengan pendekatan penelitian bahasa, yaitu pendekatan formal (sebagai oposisi dari pendekatan fungsional). Dalam penelitian ini penggunaan pendekatan formal itu berupa analisis tentang ketepatan penggunaan preposisi dalam karangan siswa kelas III, IV, V, dan VI SD. Karena analisis ketepatan penggunaan preposisi ini dilakukan dalam penggunaan bahasa yang sesungguhnya yang berupa karangan, analisis preposisi dalam penelitian ini selalu dikaitkan dengan digunakannya preposisi dalam kalimat-kalimat itu.

\section{HASIL}

Analisis data ini dilakukan pada setiap tingkatan kelas. Dengan cara demikian, diperoleh temuan penelitian tentang ketepatan penggunaan preposisi di setiap tingkatan kelas itu. Selain itu, diperoleh pula temuan penelitian komparatif di antara tingkatan kelas itu.

Dalam analisis data,ketepatan penggunaan preposisi dipilahmenjadidua kategori, yaitu ketepatan dari segi gramatika dan ketepatan dari segi penulisan. Ketepatan dari segi gramatika mengacu pada perlu tidaknya sebuah preposisi digunakan dalam kalimatdan sesuai tidaknya preposisi yang dipilih dengan konteks kalimat. Sementara itu, ketepatan dari segi penulisan mengacu pada ketepatan preposisi dari segi teknis, yaitu ejaan dan spasi.

Secara umum, siswa kelas III, IV, V, dan VI SD sudah mampu menggunakan preposisi dengan tepat. Meskipun demikian, ada pula siswa yang menggunakan preposisi dengan tidak tepat. Ketidaktepatan tersebut yaitu ketidaktepatan dari segi gramatika dan ketidaktepatan dari segi penulisan. 
Berdasarkan analisis data, dapat dikemukakan 6 temuan penelitian. Keenam temuan penelitian tersebut dikemukakan berikut.

Pertama, berdasarkan paparan data ketepatan penggunaan preposisi dalam karangan siswa kelas III SD dapat dikemukakan bahwa sudah ada siswa yang menggunakan preposisi secara tepat. Ketepatan tersebut dikategorikan menjadi dua macam, yaitu ketepatan dari segi gramatika dan ketepatan dari segi penulisan. Sementara itu, masih ada pula siswa yang menggunakan preposisi dengan tidak tepat. Ketidaktepatan tersebut dikategorikan menjadi dua macam, yaitu ketidaktepatan dari segi gramatika yang mencakup (a) penggunaan preposisi yang berlebihan, dan (b) penggunaan jenis preposisi yang tidak sesuai dengan konteks kalimat; serta ketidaktepatan dari segi penulisan.

Berikut ini dipaparkan secara berturut-turut data ketepatan penggunaan preposisi dari segi gramatika dan ketepatan dari segi penulisan yang ditemukan dalam karangan siswa kelas III.

(001) Saat hari Minggu, ayah mengajak pergi ke Rumah NENEK. (KR/III/32)

(002) Pegunungan di desa sangat indah sekali. (AR/III/23)

Pada kalimat (001) preposisi saat sudah digunakan secara tepat dari segi gramatika. Pada kalimat (002) preposisi $\boldsymbol{d i}$ sudah digunakan secara tepat dari segi penulisan. Sementara itu, ketidaktepatan penggunaan preposisi dari segi gramatika dan dari segi penulisan dalam karangan siswa kelas III dapat dicermati pada contoh berikut.

(003) Aku merasa senang bisa mengelilingi ke Bali yang luas dan indah. (KR/III/23)

(004) Saya disana diajak keliling-keliling sampai melihat jembatan kereta api (KR/III/11)

(005) Di situ banyak teman-teman samah ayah disuru ke rumah nenek... (KR/III/5)

Pada kalimat (003) terdapat ketidaktepatan penggunaan preposisi dari segi gramatika berupa penggunaan preposisi yang berlebihan. Ketidaktepatan tersebut terletak pada penggunaan preposisi $\boldsymbol{k} \boldsymbol{e}$ sehingga menyebabkan kalimatnya menjadi tidak gramatikal. Seharusnya, kalimat tersebut tidak menggunakan preposisi $\boldsymbol{k e}$.

Pada kalimat (004) terdapat ketidaktepatan penggunaan preposisi dari segi pilihan jenis preposisi. Ketidaktepatan tersebut terletak pada penggunaan preposisi sampai yang tidak sesuai dengan konteks kalimat sehingga menyebabkan kalimatnya menjadi tidak gramatikal. Seharusnya, kalimat tersebut menggunakan preposisi untuk.

Pada kalimat (005) terdapat kesalahan dalam menggunakan preposisi. Preposisi yang dimaksud yaitu preposisi samah, yaitu kesalahan yang berupa penambahan huruf $\boldsymbol{h}$ pada preposisi sama. Seharusnya, kata sama ditulis dengan empat huruf, yaitu $\boldsymbol{s}-\boldsymbol{a}-\boldsymbol{m}-\boldsymbol{a}$, tanpa menggunakan huruf $\boldsymbol{h}$.

Kedua, berdasarkan paparan data ketepatan penggunaan preposisi dalam karangan siswa kelas IV SD dapat dikemukakan bahwa sudah ada siswa yang menggunakan preposisi secara tepat.Ketepatan tersebut dikategorikan menjadi tiga macam, yaitu ketepatan dari segi gramatika, ketepatan dari segi pemilihan jenis preposisi, dan ketepatan dari segi penulisan. Sementara itu, masih ada pula siswa yang menggunakan preposisi dengan tidak tepat. Ketidaktepatan tersebut dikategorikan menjadi dua macam, yaitu ketidaktepatan dari segi pemilihan jenis preposisi dan ketidaktepatan dari segi penulisan.

Berikut ini dipaparkan secara berturut-turut data ketepatan penggunaan preposisi dari segi gramatika, ketepatan dari segi pemilihan jenis preposisi, dan ketepatan dari segi penulisan yang ditemukan dalam karangan siswa kelas IV.

(006) Lalu oleh supir bus tadi semua penumpang disuruh turun dari bus. (CM/IV/03) 
(007) Aku langsung mencari makan didepan hotel dengan keluargaku. (KP/IV/07).

(008) Bintang memancing dengan pancing besar. (KP/IV/13)

Pada kalimat (006) preposisi dari sudah digunakan secara tepat dari segi gramatika. Pada kalimat (007) preposisi dengan sudah digunakan secara tepat dari segi pemilihan jenis preposisi sehingga kalimat tersebut terterima dan sesuai dengan konteks kalimat. Pada kalimat (008) preposisi dengan sudah digunakan secara tepat dari segi penulisan.

Sementara itu, ketidaktepatan penggunaan preposisi dari segi pemilihan jenis preposisi dan ketidaktepatan dari segi penulisan dalam karangan siswa kelas IV dapat dicermati pada contoh berikut.

(009) Aku bersiap-siap akan turun ke kereta api, membawa barang barang yg besar itu kerjaan dari ayahku.... (AR/IV/29)

(010) Saya langsung pulang ke rumah tante saya dan keesokan harinya saya pergi ke kepanjen. (KP/IV/25)

Pada kalimat (009) terdapat ketidaktepatan penggunaan preposisi dari segi pilihan jenis preposisi. Ketidaktepatan tersebut terletak pada penggunaan preposisi $\boldsymbol{d i}$ yang tidak sesuai dengan konteks kalimat sehingga menyebabkan kalimatnya tidak gramatikal. Seharusnya, kalimat tersebut menggunakan preposisi $\boldsymbol{k} \boldsymbol{e}$.

Pada kalimat (010) terdapat kesalahan dalam menggunakan preposisi $\boldsymbol{k e}$, yaitu kesalahan teknis yang berupa penulisan preposisi $\boldsymbol{k} \boldsymbol{e}$ yang digabung dengan nomina yang berada di kanannya. Seharusnya, preposisi ke pada kalimat tersebut ditulis terpisah dengan nomina yang terletak di sebelah kanannya. Dengan demikian, preposisi tersebut seharusnya ditulis kerumah(ke spasi rumah).

Ketiga, berdasarkan paparan data ketepatan penggunaan preposisi dalam karangan siswa kelas V SD dapat dikemukakan bahwa sudah ada siswa yang menggunakan preposisi secara tepat. Ketepatan tersebut dikategorikan menjadi tiga macam, yaitu ketepatan dari segi gramatika, ketepatan dari segi pemilihan jenis preposisi, dan ketepatan dari segi penulisan. Sementara itu, masih ada pula siswa yang menggunakan preposisi dengan tidak tepat. Ketidaktepatan tersebut dikategorikan menjadi dua macam, yaitu ketidaktepatan dari segi pemilihan jenis preposisi dan ketidaktepatan dari segi penulisan.

Berikut ini dipaparkan secara berturut-turut data ketepatan penggunaan preposisi dari segi gramatika, ketepatan dari segi pemilihan jenis preposisi, dan ketepatan dari segi penulisan yang ditemukan dalam karangan siswa kelas $\mathrm{V}$.

(011) Lalu Rina berlari menuju rumahnya. (AR/V/11)

(012) Sejak pertemuan pertama itu Bandung Bondowoso mencintai Roro Jonggran. $(\mathrm{KR} / \mathrm{VI} / 21)$

(013) Lalu aku di beri kue ulang tahun dan di beri kado oleh ayah dan ibu. (AR/V/34)

Pada kalimat (011) preposisi menuju sudah digunakan secara tepat dari segi gramatika. Pada kalimat (012) preposisi sejak sudah digunakan secara tepat dari segi pemilihan jenis preposisi sehingga membuat kalimat tersebut terterima dan sesuai dengan konteks kalimat. Pada kalimat (013) preposisi oleh sudah digunakan secara tepat dari segi penulisan.

Sementara itu, ketidaktepatan penggunaan preposisi dari segi pemilihan jenis preposisi dan ketidaktepatan dari segi penulisan dalam karangan siswa kelas $\mathrm{V}$ dapat dicermati pada contoh berikut.

(014) Ke dalam kereta itu aku tertidur. (CM/V/04)

(015) Aku dan keluarga Berlibur Ke kota Batu yang sangat indah. (CM/V/18) 
Pada kalimat (014) terdapat ketidaktepatan penggunaan preposisi dari segi pilihan jenis preposisi. Ketidaktepatan tersebut terletak pada penggunaan preposisi kedalam (ke dalam) yang tidak sesuai dengan konteks kalimat sehingga menyebabkan kalimatnya menjadi tidak gramatikal. Seharusnya, kalimat tersebut menggunakan preposisi di dalam .

Pada kalimat (015) terdapat dua kesalahan dalam menggunakan preposisi $\boldsymbol{k e}$, yaitu kesalahan yang berupa penggunaan huruf kapital di tengah kalimat dan penulisan preposisi $\boldsymbol{k} \boldsymbol{e}$ yang digabung dengan nomina yang terletak di sebelah kanannya. Dalam konteks kalimat tersebut, preposisi ke terletak di tengah kalimat sehingga seharusnya ditulis menggunakan huruf kecil. Selain itu, $\boldsymbol{k} \boldsymbol{e}$ adalah preposisi sehingga seharusnya ditulis terpisah (dibubuhi spasi) dengan nomina yang terletak di sebelah kanannya. Oleh karena itu, preposisi tersebut seharusnya ditulis ke Kota Batu (ke spasi kota).

Keempat, berdasarkan paparan data ketepatan penggunaan preposisi dalam karangan siswa kelas VI SD dapat dikemukakan bahwa sudah ada siswa yang menggunakan preposisi secara tepat. Ketepatan tersebut dikategorikan menjadi tiga macam, yaitu ketepatan dari segi gramatika, ketepatan dari segi pemilihan jenis preposisi, dan ketepatan dari segi penulisan. Sementara itu, masih ada pula siswa yang menggunakan preposisi dengan tidak tepat. Ketidaktepatan tersebut dikategorikan menjadi tiga macam, yaitu ketidaktepatan dari segi gramatika, ketidaktepatan dari segi pemilihan jenis preposisi, dan ketidaktepatan dari segi penulisan.

Berikut ini dipaparkan secara berturut-turut data ketepatan penggunaan preposisi dari segi gramatika, ketepatan dari segi pemilihan jenis preposisi, dan ketepatan dari segi penulisan yang ditemukan dalam karangan siswa kelas VI.

(016) Ternyata itu adalah undangan untuk juara 3 Olimpiade Matematika dalam acara Grand

Final PMJ (Primagama Mencari Juara) se jatim. (KP/VI/19)

(017) Nenekku juga bercerita tentang masa penjajahan. (AR/VI/30)

(018) Karena akan terjadi hujan lebat, lalu Samosir pergi ke atas bukit. (KR/VI/24)

Pada kalimat (016) preposisi dalam sudah digunakan secara tepat dari segi gramatika. Pada kalimat (017) preposisi tentang sudah digunakan secara tepat dari segi pemilihan jenis preposisi sehingga kalimat tersebut terterima dan sesuai dengan konteks kalimat. Pada kalimat (018) preposisi ke atas sudahdigunakan secara tepat dari segi penulisan.

Sementara itu, ketidaktepatan dari segi gramatika, ketidaktepatan dari segi pemilihan jenis preposisi, dan ketidaktepatan dari segi penulisandalam karangan siswa kelas VI dapat dicermati pada contoh berikut.

(019) Di sanabanyak sekali pengunjung dari turis. (KR/VI/22)

(020) Lalu dengan ibuku disediakan makanan seperti gorengan dan diberi minuman es teh.

$(\mathrm{CM} / \mathrm{VI} / 06)$

(021) Walau luka itu sangat sakit, karena kita menghadapi dgn bersama akan terasa lebih ringan. (AR/VI/27)

Pada kalimat (019) terdapat ketidaktepatan penggunaan preposisi dari segi gramatika berupa penggunaan preposisi yang berlebihan. Ketidaktepatan tersebut terletak pada penggunaan preposisi dari sehingga menyebabkan kalimatnya menjadi tidak gramatikal. Seharusnya, kalimat tersebut tidak perlu menggunakan preposisi dari.

Pada kalimat (020) terdapat ketidaktepatan penggunaan preposisi dari segi pilihan jenis preposisi. Ketidaktepatan tersebut terletak pada penggunaan preposisi dengan yang tidak sesuai dengan konteks kalimat sehingga menyebabkan kalimatnya menjadi tidak gramatikal. Seharusnya, kalimat tersebut menggunakan preposisi $\boldsymbol{d a r i}$. 
Pada kalimat (021) terdapat ketidaktepatan dalam menggunakan preposisi dgn, yaitu ketidaktepatan teknis yang berupa penyingkatan preposisi dengan menjadi dgn.Seharusnya, preposisi $\boldsymbol{d g n}$ pada kalimat tersebut tidak disingkat karena karangan yang ditulis oleh siswa adalah karangan yang bersifat formal. Dengan demikian, preposisi tersebut seharusnya ditulis dengan.

Kelima, berdasarkan komparasi paparan data ketepatan penggunaanpreposisi dalam karangan siswa kelas III, IV, V, dan VI SD dapat dikemukakan bahwa siswa di semua jenjang kelas menggunakan preposisi secara tepat. Ketepaan tersebut yaitu ketepatan dari segi gramatika, ketepatan dari segi pemilihan jenis preposisi, dan ketepatan dari segi penulisan. Sementara itu, ditemukan pula ketidaktepatan penggunaan preposisi yang ada di semua jenjang kelas. Ketidaktepatan yang penggunaan preposisi yang terdapat pada semua jenjang kelas adalah ketidaktepatan dari segi pemilihan jenis preposisi dan ketidaktepatan dari segi penulisan.

Keenam, berdasarkan komparasi paparan data ketepatan penggunaan preposisi dalam karangan siswa kelas III, IV, V, dan VI SD dapat dikemukakan bahwa ada ketidaktepatan penggunaan preposisi yang hanya ditemukan di jenjang kelas III dan kelas VI saja. Ketidaktepatan tersebut yaitu ketidaktepatan dari segi gramatika.

Untuk memperjelas perbedaan ketepatan penggunaan preposisi dalam karangan siswa kelas III, IV, V, dan VI, disajikan tabel 6.1.

Tabel 1 Ketepatan Penggunaan Preposisi dalam Karangan Siswa Kelas III, IV, V, dan VI

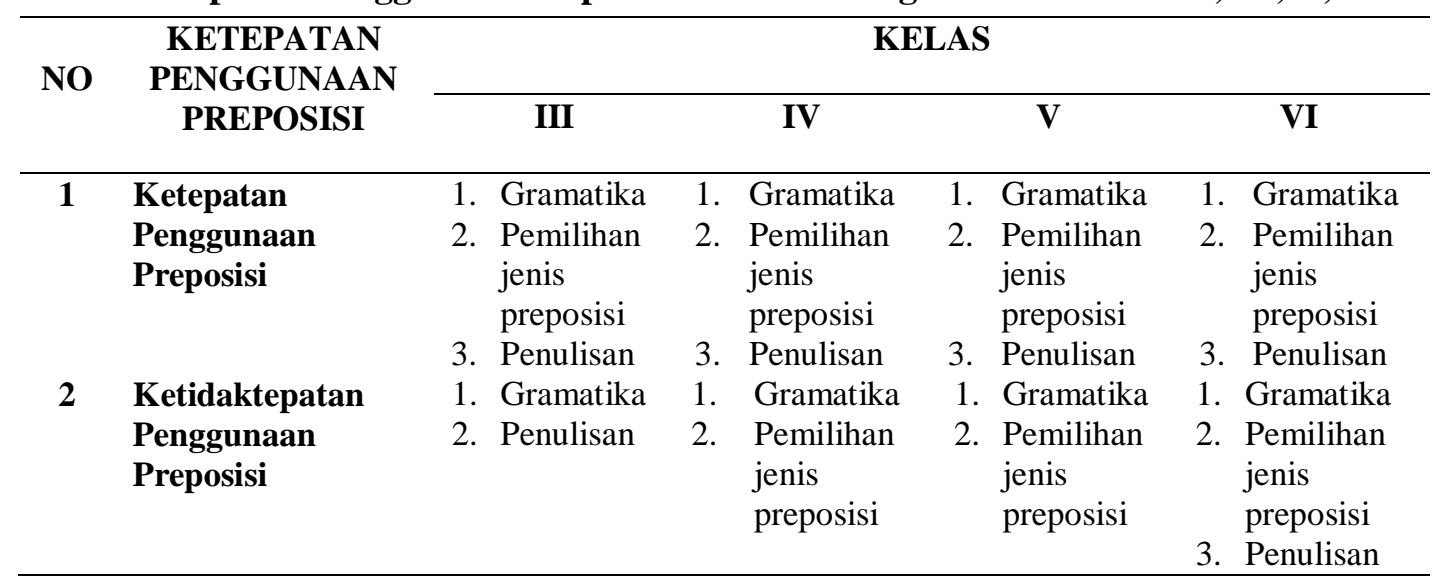

\section{PEMBAHASAN}

Berdasarkan analisis data, dapat diketahui bahwa sebagian besar siswa kelas III, IV, V, dan VI SD sudah mampu menggunakan preposisi dengan tepat. Berkaitan dengan temuan penelitian ini, dapat dikemukakan pembahasan berikut.

Dari segi pemerolehan, dapat diketahui bahwa siswa kelas III, IV, V, dan VI SD sudah mampu menggunakan preposisi secara bervariasi dalam karangan. Bahkan, semakin bertambah jenjang kelasnya, semakin bertambah pula preposisi yang dikuasai siswa. Hal ini menunjukkan bahwa siswa sudah cukup banyak menguasai preposisi dan mampu menggunakan preposisi tersebut dengan tepat. Oleh karena itu, dapat diasumsikan bahwa kompetensi komunikasi siswa kelas III, IV, V, dan VI sudah berkembang dengan sempurna.

Kompetensi komunikasi yang sudah berkembang dengan sempurna ditandai dengan penggunaan preposisi dengan tepat, baik dari segi gramatika, segi pemilihan jenis preposisi, dan segi penulisan. Dari segi gramatika, siswa sudah mampu membuat sebuah keputusan 
perlu-tidaknya sebuah kalimat itu menggunakan preposisi. Jika intuisi bahasanya merasa tidak perlu menggunakan preposisi, maka siswa tidak menggunakan preposisi dalam karangannya. Hal ini akan membuat kalimat-kalimat yang disusunnya gramatis (terterima). Dari segi pemilihan jenis preposisi, siswa juga sudah mampu menentukan preposisi yang tepat untuk digunakan dalam kalimat yang disusunya. Misalnya siswa dihadapkan pada lebih dari satu preposisi, siswa sudah dapat menentukan preposisi yang paling tepat dengan konteks kalimat yang disusunnya sehigga kalimat yang disusunnya menjadi grmatis (terterima). Dari segi penulisan, siswa juga sudah mampu menulis preposisi dengan tepat. Ketepatan tersebut berupa ketepatan dari segi jumlah dan anggota huruf penyusun preposisi, dari segi penulisan huruf kapital dan huruf kecil, serta dari segi pembubuhan spasi.

Dalam menyusun karangan, dapat diketahui bahwa siswa berusaha agar karangan yang disusunya dapat dipahami dengan baik oleh pembaca. Oleh karena itu, siswa berusaha memberi keterangan dalam karangan untuk memperjelas maksud kalimat. Upaya ini dilakukan dengan cara menggunakan preposisi dalam karangan yang disusunnya. Berkenaan dengan pandangan itu, dikemukakan pula pembahasan dari segi pragmatik.

Pada saat seseorang menyusun kalimat, pada dasarnya orang tersebut sedang memberdayakan bahasa untuk menciptakan komunikasi yang efektif. Untuk menciptakan komunikasi yang efektif tersebut, seorang penutur akan memperhatikan konteks terjadinya tuturan. Konteks yang dimaksud meliputi pembicara, pendengar, pesan, latar atau situasi, saluran, dan kode (Stubbs, 1983). Dalam rangka menciptakan konteks demi menciptakan komunikasi yang efektif itulah, preposisi didayagunakan. Jika preposisi digunakan dengan tepat, maka diasumsikan bahwa kalimat akan lebih mudah dipahami oleh petutur dan informasi yang diperoleh petutur juga semakin jelas. Dengan demikian, dapat dimaknai pula bahwa penggunaan preposisi secara tepat secara pragmatis juga menunjukkan bahwa kompetensi berbahasa siswa kelas III, IV, V, dan VI SD sudah sempurna.

Dalam sebuah karangan, preposisi biasanya digunakan sebagai penanda Ket kalimat. Artinya, jika ada sebuah konstituen dalam kalimat yang diawali dengan preposisi, kemungkinan besar konstituen itu menduduki fungsi Ket. Sejalan dengan temuan penelitian ini, diketahui pula bahwa dalam karangan siswa kelas III, IV, V, dan VI SD, fungsi Ket ditandai dengan penggunaan preposisi di bagian awal konstituennya. Hal ini dapat dimaknai bahwa kompetensi berbahasa sekaligus kompetensi berpikir siswa sudah sempurna.Temuan ini sekaligus mendukung pendapat Finegan \& Besnier (1993) yang menyatakan bahwa bahasa mempengaruhi pikiran dan pikiran mempengaruhi bahasa. Hubungan tersebut bersifat dua arah, bukan satu arah.

Meskipun secara umum siswa sudah mampu menggunakan preposisi dengan tepat, ada pula siswa yang menggunakan preposisi denga tidak tepat. Ketidakteptan tersebut dapat dikategorikan menjadi tiga macam, yaitu ketepatan dari segi gramatika, ketepatan dari segi pemilihan jenis preposisi, dan ketepatan dari segi penulisan. Berkaitan dengan ketidaktepatan penggunaan preposisi dalam karangan siswa kelas III, IV, V, dan VI SD tersebut, dapat dikemukakan pembahasan berikut.

Dari segi ragam bahasa yang digunakan dalam karangan, diketahui bahwa ragam bahasa yang digunakan dalam karangan siswa kelas III, IV, V, dan VI SD adalah ragam bahasa konsultatif. Menurut Joos (1964), ragam bahasa dapat bahasa konsultatif berada di antara ragam baku (formal) dan ragam santai (kasual). Ragam konsultatif ini mendekati baku, tetapi bukan ragam baku. Karena itu, preposisi yang ditemukan dalam karangan siswa tidak semuanya digunakan dengan tepat. 
Ketidaktepatan penggunaan preposisi dalam karangan siswa juga dapat dijelaskan dari segi pemeroleh bahasa. Lazimnya, siswa kelas III, IV, V, dan VI SD adalah anak yang berada dalam tahap pemerolehan bahasa kedua. Siswa yang mayoritas bahasa pertamanya adalah bahasa Jawa tersebut sedang berada pada tahap pemerolehan bahasa Indonesia.

Pada saat mempelajari bahasa kedua, bahasa anak memiliki kekhasan. Kekhasan tersebut terwujud dalam bahasa antara (interlanguage), yaitu sistem bahasa yang digunakan oleh pelajar bahasa sebagai upaya memperoleh bahasa sasaran. Dalam penggunaan bahasa antara tersebut, Brown (2007:109-111) menyebutkan bahwa setidaknya ada tiga gejala yang terkait dengan penggunaan bahasa antara. Pertama, transfer, yaitu pengalihan pengetahuan tentang bahasa pertama ke bahasa sasaran. Kedua, interferensi, yaitu menggunakan kaidah bahasa pertama pada bahasa kedua. Ketiga, generalisasi berlebihan, yaitu menggunakan kaidah umum terhadap bahasa sasaran.

Temuan ini sejalan dengan temuan Arjan, Abdullah, \& Roslin (2013:168) yang menyatakan bahwa ketidaktepatan penggunaan preposisi disebabkan oleh pengaruh bahasa pertama. Dalam penelitiannya, Arjan, Abdullah, dan Roslin yang meneliti sejumlah mahasiswa berbahasa pertama bahasa Melayu dan berbahasa kedua bahasa Inggris mengalami kesalahan dalam menggunakan preposisi in dan on. Salah satu faktor penyebab kesalahannya adalah karena subjek penelitian tersebut masih terpengaruh bahasa pertamanya. Mereka menerapkan kaidah bahasa pertama ke dalam bahasa kedua.

Pada kasus ketidaktepatan penggunaan preposisi dalam karangan siswa, dapat diketahui bahwa ada kecenderungan siswa melakukan generalisasi terhadap bahasa sasaran. Artinya, siswa menggunakan kompetensi bahasa pertamanya untuk digunakan dalam menerapkan kaidah bahasa sasaran. Dalam hal ini, siswa menerapkan kaidah bahasa Jawa yang dikuasainya ke dalam bahasa Indonesia. Generalisasi berlebihan dapat ditemukan dalam karangan siswa pada penggunaan preposisi dengan pada contoh kalimat (022) berikut ini.

(022) Lalu dengan ibuku disediakan makanan seperti gorengan dan diberi minuman es teh.

(CM/VI/06)

Pada kalimat (022), siswa menggunakan pilihan kata bahasa Jawa yang dialihbahasakan ke dalam bahasa Indonesia. Dalam bahasa Jawa, terdapat kata karo yang dalam bahasa Indonesia berpadanan dengan kata oleh, dan, serta, dan dengan. Dalam konteks kalimat tersebut, preposisi yang seharusnya digunakan adalah preposisi oleh yang berpadanan dengan kata karo. Namun, karena keterbatasan kosakata ataupun kompetensi berbahasa siswa, siswa memadankan kata karo dalam bahasa Jawa dengan kata dengan. Padahal, dalam konteks kalimat tersebut, kata karo dalam bahasa Jawab erpadanan dengan kata oleh dalam bahasa Indonesia.

Ketidaktepatan yang lain yang dapat ditemukan dalam karangan siswa yaitu penggunaan kata sama seperti yang terdapat pada kalimat (023) berikut ini.

(023) Sudah hampir lama aku berenang aku dibelikan Yakult sama kakakku.(CM/VI/17)

Pada kalimat (023) siswa menggunakan kata sama. Dalam Kamus Besar Bahasa Indonesia, kata sama berkelas kata ajektiva dan bermakna '(1) mirip, tidak berbeda, tidak berlainan; (2) berbarengan, bertepatan; dan (3) sepadan, seimbang, sebanding, setara'. Namun, dalam karangan, siswa menggunakan kata sama sebagai preposisi. Padahal, sebenarnya preposisi yang seharusnya digunakan adalah bersama. Dengan demikian, siswa sebenarnya melakukan penyederhanaan dalam menggunakan preposisi bersama yang diwujudkan dalam kata sama. Penyederhanaan ini dapat dipahami karena siswa masih dalam 
masa pemerolehan bahasa kedua (bahasa Indonesia). Dalam masa ini, siswa cenderung menyimpan dan menggunakan kata dalam bentuk sederhana, yaitu dalam bentuk dasar.

Penggunaan preposisi yang tidak tepat juga dapat dijelaskan dari segi perbendaharaan kosakata yang dimiliki siswa. Dalam masa pemerolehan bahasa kedua, sangat mungkin jika siswa hanya menguasai beberapa kosakata saja. Oleh karena itu, siswa akan menggunakan kosakata lain yang maknanya "mirip" untuk menggantikan kosakata lain yang tidak dia kuasai. Bahkan, mungkin pula ia menggunakan kosakata bahasa pertamanya dana mengalihbahasakan begitu saja kosakata bahasa pertamanya ke dalam bahasa sasaran.

Terkait dengan ketidaktepatan dari segi penulisan, dapat dijelaskan bahwa ketidaktepatan penulisan tersebut ditengarai disebabkan oleh kurangnya penguasaan siswa terhadap kaidah bahasa sasaran. Misalnya, kaidah dalam bahasa Indonesia menyebutkan bahwa awal kalimat harus dimulai dengan huruf kapital dan huruf kapital tidak digunakan di tengah kalimat, kecuali nama. Namun, karena tidak memahami kaidah ini, siswa menggunakan huruf kecil di awal kalimat atau menggunakan huruf kapital di tengah kalimat.

Pada karangan siswa kelas VI, ditemukan pula ketidaktepatan dalam bentuk penyingkatan penulisan preposisi. Jika dikaitkan dengan ragam bahasa yang digunakan, karangan yang ditulis oleh siswa adalah karangan yang menggunakan ragam bahasa konsultatif, yaitu ragam bahasa yang berada di antara ragam baku (formal) dan ragam santai (kasual). Ragam konsultatif ini mendekati baku, tetapi bukan ragam baku. Oleh karena itu, sangat mungkin siswa menggunakan singkatan dalam tulisannya.

Walton (2009) menyebut singkatan sebagai "shortening of words, shorthand, or shortened language".Singkatan adalah "words that make it easier to communi-cate". Singkatan biasanya digunakan agar komunikasi menjadi lebih efektif. Namun, singkatan lazimnya digunakan untuk bahasa lisan yang dituliskan (misalnya sms, obrolan elektronik [chatting], maupun status dan komentar di media sosial) lebih dimaksudkan untuk efektivitas komunikasi. Oleh karena itu, penggunaan singkatan dalam obrolan dimaksudkan agar komunikasi dapat berjalan dengan lebih efektif.

Di sisi lain, teknologi komunikasi berkembang dengan pesat dan dimanfaatkan banyak kalangan. Salah satunya adalah siswa. Pada saat ini, banyak ditemui bahwa anak usia SD sudah banyak yang memanfaatkan perkembangan teknologi komunikasi, misalnya menggunakan telepon genggam. Hal ini dapat disimpulkan bahwa anak usia kelas VI SD banyak yang sudah memanfaatkan telepon genggam untuk komunikasinya.

Dalam menggunakan telepon genggam tersebut, lazim digunakan singkatan. Ragam bahasa yang demikian ini oleh Goytisolo (2001) disebut sebagai kelisanan sekunder. Dalam situasi kelisanan sekunder, teks tertulis sering mendasari informasi lisan. Artinya, seseorang berbahasa secara tulis, tetapi hakikat bahasanya adalah bahasa lisan.

Intensitas kelisanan sekunder yang tinggi dapat terjadi pada komunikasi menggunakan telepon genggam, misalnya melalui pesan singkat (short messege service [sms]).Apalagi, saat ini kelisanan sekunder dalam dunia teknologi informasi dan komunikasi menjadi bagian dari kehidupan beberapa komunitas masyarakat (UNESCO, 2002:18). Hal ini menyebabkan kelisanan primer (bahasa tulis) siswa terpengaruh oleh kelisanan sekunder. Oleh karena itu, siswa yang terbiasa melakukan kelisanan sekunder tersebut bisa jadi menggunakannya dalam bahasa tulisnya.Itulah sebabnya pula, ditemukan singkatan dalam karangan siswa. 


\section{DAFTAR RUJUKAN}

Arjan, A., Abdullah, N.H., \& Roslim, N. 2013.A Corpus-Based Study on English Prepositions of Place, in and on. Journal of English Language Teaching Vol 6 No 12 page $167-174$.

Brown, H.D. 2007. Prinsip Pembelajaran dan Pengajaran Bahasa.Terjemahan oleh Noor Cholis dan Yusi Avianto Pareanom. 2008. Jakarta: Kedutaan Besar Amerika Serikat, Perarson Education Inc.

Fenegan, E. \& Besnier, N. 1993.The Relationship between Language and Thought. Dalam Fishman, J. (Ed.), Reading in the Sociology of Language. The Hague: Mouton.

Goytisolo, J. 2001. Proclamation of Masterpieces of the Oral and Intangible Heritage of Humanity: Defending Threaten Cultures. http://www.unesco.org/bpi/intangible heritage/goytisoloe.htm.(Diunduh tanggal 22 Mei 2011).

Joos, M. 1964. The Five Clocks. New York: Harcourt-Brace World Inc.

Nurchasanah \& Widodo Hs. 1993. Keterampilan Menulis dan Pengajarannya. Malang: IKIP Malang.

Rofila, A.F. 2006. Penggunaan Preposisi dalam Karangan Siswa Kelas VIII SMP Negeri 4 Malang Tahun Ajaran 2005/2006. Skripsi tidak diterbitkan. Malang: Fakultas Sastra Universitas Negeri Malang.

Stubs, M. 1983. Discourse Analysis: The Sociolingustic Analysis of Natural Language. Chicago: University of Chicago Press.

UNECSO. 2002. Information and Communication Technology in Education. Paris: Division of Higher Education UNESCO.

Walton, M. 2009. Mobile Literacies and South African Teens: Leisure Reading, Writing, and MXit Chatting for Teens in Langa and Gugutelu. Cape Town: Center for Film and Media Studies University of Cape Town. 